Indo. J. Chem. Res., 2019, 7(1), 9-24

\title{
STUDI POTENSI PIRAZOLIN TERSUBSTITUSI 1-N DARI TIOSEMIKARBAZON SEBAGAI AGEN ANTIAMUBA MELALUI UJI IN SILICO
}

\section{Study of Potential of 1-N-Substituted Pyrazoline Analogues of Thiosemicarbazones as Antiamoebic Agent using In Silico Screening}

\author{
Akram La Kilo $^{1 *}$, La Ode Aman', Ismail Sabihi ${ }^{2}$, Jafar La Kilo $^{1}$ \\ ${ }^{I}$ Chemistry Study Program, Faculty of Mathematics and Natural Sciences, Gorontalo State University, \\ Jl. Jenderal Sudirman No. 6 Kota Gorontalo \\ ${ }^{2}$ Chemical Education Study Program, Faculty of Mathematics and Natural Sciences, Gorontalo State \\ University,, Jl. Jenderal Sudirman No. 6 Kota Gorontalo \\ *Corresponding author, e-mail: akram@ung.ac.id
}

Received: Mar. 2019 Published: Jul. 2019

\begin{abstract}
This Research aims to study Quantitative Structure-Activity Relationship (QSAR) of pyrazoline analogues, designing the new potential compounds as antiamoebic and study the interactions between the new compunds and the drugs target by molecular docking approach. This research was a theoritical research using computational chemistry method. The object of research was 21 novel of $1-\mathrm{N}$-substituted pyrazoline analogues of thiosemicarbazones with their antiamoebic biological activity. The data of research was obtained from quantum chemistry calculation and statistically analysis using Multiple Linear Regression (MLR). The resulting QSAR equation was $\log \mathrm{IC}_{50}=0.869+(0.081 \times \mathrm{TPSA})+(0.018 \times \mathrm{HF})+(0.527 \times \mathrm{E}-\mathrm{HOMO})+(3.378 \times \mathrm{E}-$ LUMO $)+(-16.938 \times$ Glob $)+(0.234 \times \log P)$, with statistic parameters of $n=21 ; R^{2}=0.933 ;$ SEE $=0.14558$; $\mathrm{F}_{\text {Hitung }} / \mathrm{F}_{\text {Tabel }}=8.607$; PRESS $=0.491$. This equation was used as a basic for designing and predicting the new antiamoebic compounds of pyrazoline analogues. The design of new compound of two lead compounds with the Topliss resulted 5 of 18 new compounds having theoretical better activity than the lead compound. Molecular docking study indicated that all of the best compounds have ability to bind to drug target macromolecule.
\end{abstract}

Keywords: Antiamoebic, In Silico, QSAR, Molecular Docking

\section{PENDAHULUAN}

Senyawa heterosiklik yang telah banyak dieksplorasi untuk pengembangan molekul obat dalam farmasi adalah pirazolin (Sharma dkk., 2014). Pirazolin adalah turunan dihidropirazol yang merupakan senyawa golongan azol dengan struktur heterosiklik-5 yang mengandung 2 atom nitrogen (Bhoyar dkk., 2011). Pirazolin diketahui mempunyai bioaktivitas seperti antiinflamasi, antimikroba, antibakteri, antidiabetes, dan antipiretik (Mangeron, 2006).

Setiap senyawa turunan pirazolin memiliki aktivitas biologis tertentu sesuai jenis substituen yang terdapat di dalamnya. Turunan pirazolin yang potensial sebagai antiamuba diantaranya adalah analog Pirazolin dari thiosemicarbazon. Abid dan Azam (2005) telah melaporkan bahwa senyawa analog Pirazolin tersubstitusi $1-N$ dari thiosemicarbazon memiliki nilai aktivitas antiamuba yang lebih baik daripada metronidazole yang merupakan obat yang umumnya digunakan untuk mengobati penyakit amubiasis.

Amubiasis merupakan suatu infeksi yang disebabkan oleh protozoa saluran cerna, yakni Entamoeba hystolitica (E. hystolitica). Penyakit ini adalah penyebab utama ketiga kematian akibat penyakit parasit di seluruh dunia setelah malaria dan schistosomiasis. Menurut estimasi, sekitar 48 juta individu di seluruh dunia menderita amubiasis. Di Indonesia, prevalensi Entamoeba histolytica sekitar 10-18\% (Widyastuti, 2011).

Proses penemuan dan pengembangan obat antibiotik baru memerlukan waktu sepuluh tahun yang meliputi tiga tahun untuk penemuan (discovery) dan tujuh tahun untuk pengembangan. Proses penemuan obat antibiotik baru memerlukan langkah-langkah eksperimen yang meliputi desain, sintesis, purifikasi, identifikasi dan uji aktivitas. Setiap langkah dalam penemuan obat antibiotik baru sangat kompleks, membutuhkan biaya besar dan waktu 
yang lama serta kemungkinan kesalahannya besar (Damme, 2009).

Aplikasi metode kimia komputasi dalam aktivitas penemuan dan pengembangan senyawa obat baru telah menjadi populer. Hal ini dikarenakan metode yang juga disebut in silico ini menawarkan strategi ekonomis dan upaya efektif untuk penemuan obat baru dengan memanfaatkan kemampuan komputer dalam melakukan simulasi dan kalkulasi seperti optimasi aktivitas, geometri, dan reaktivitas, sebelum senyawa disintesis secara eksperimental.

Hubungan Kuantitatif Struktur-Aktivitas (HKSA) atau Quantitative Structure-Activity Relationship (QSAR) merupakan analisis pencarian keterkaitan antara aktivitas biologis dari suatu seri senyawa dengan sifat fisikokimia yang diekspresikan dengan persamaan matematis (Putri dan Tahir, 2004). Metode statistik yang lazim digunakan dalam kajian HKSA adalah Regresi Linier Berganda atau Multiple Linear Regression (MLR). Filosofi molecular docking didasarkan pada pemanfaatan informasi struktur target (reseptor) maupun sifat fisikokimia ligan (obat) untuk melakukan uji interaksi senyawa obat pada prediksi sisi aktif protein (Pranowo, 2009).

\section{METODOLOGI}

Penelitian ini menggunakan metode HKSA yang dikembangkan oleh Hancsh, dengan bantuan aplikasi MOE yang memiliki fasilitas analisis QSAR. Teknik analisis data yang digunakan untuk menentukan persamaan HKSA adalah statistika Regresi Linier berganda atau Multiple Linear Regression (MLR).

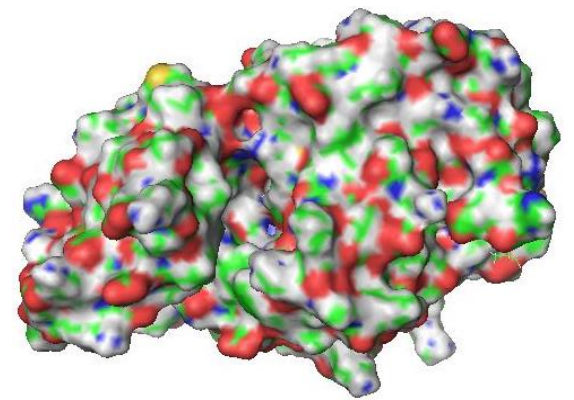

Gambar 1. Struktur molekul reseptor EHOASS (visualisasi PyMOL)

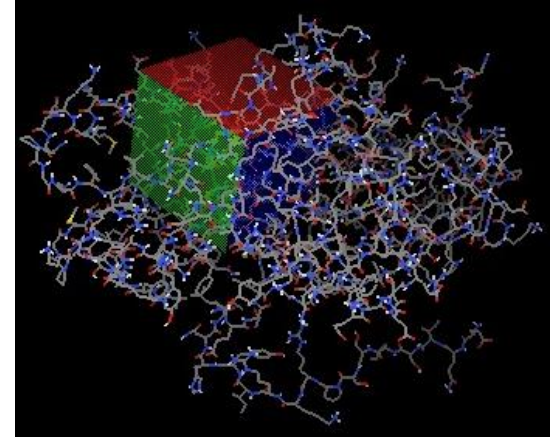

Gambar 2. Grid box docking pada aplikasi AutoDock Tools 4.2.6<smiles>CCCCN(C)C(=S)N1CCC(c2cccc(Cl)c2)=N1</smiles>

(a)<smiles>CCCN(CCC)C(=S)N1CCC(c2cccc(Cl)c2)=N1</smiles>

(b)

Gambar 3. (a) Senyawa penuntun 15 , (b) Senyawa penuntun 21

Analisis ini dilakukan dengan bantuan software SPSS versi 21.0, dimana variabel terikat $(y)$ adalah nilai logaritma aktivitas biologis $\left(\log \mathrm{IC}_{50}\right)$ senyawa turunan pirazolin dan variabel bebas $(x)$ adalah deskriptor. Luaran hasil analisis regresi linier berganda adalah parameter statistik berbagai model kombinasi deskriptor yang dihubungkan dengan nilai $\log \mathrm{IC}_{50}$, yakni nilai koefisien korelasi $(r)$, koefisien determinasi $\left(r^{2}\right)$, Standard Error of Estimate (SEE) dan nilai Fischer $\left(\mathrm{F}_{\text {hitung }}\right)$. Persamaan HKSA digunakan untuk merancang usulan senyawa baru turunan pirazolin yang memiliki aktivitas biologis (antiamuba) yang lebih efektif. Interaksi antara senyawa yang diusulkan dengan reseptor obat dikaji menggunakan metode molecular docking dengan bantuan perangkat lunak AutoDock Tools 4.2.6 dan AutoDock Vina. 
La Kilo dkk. / Indo. J. Chem. Res., 2019, 7(1), 9-24

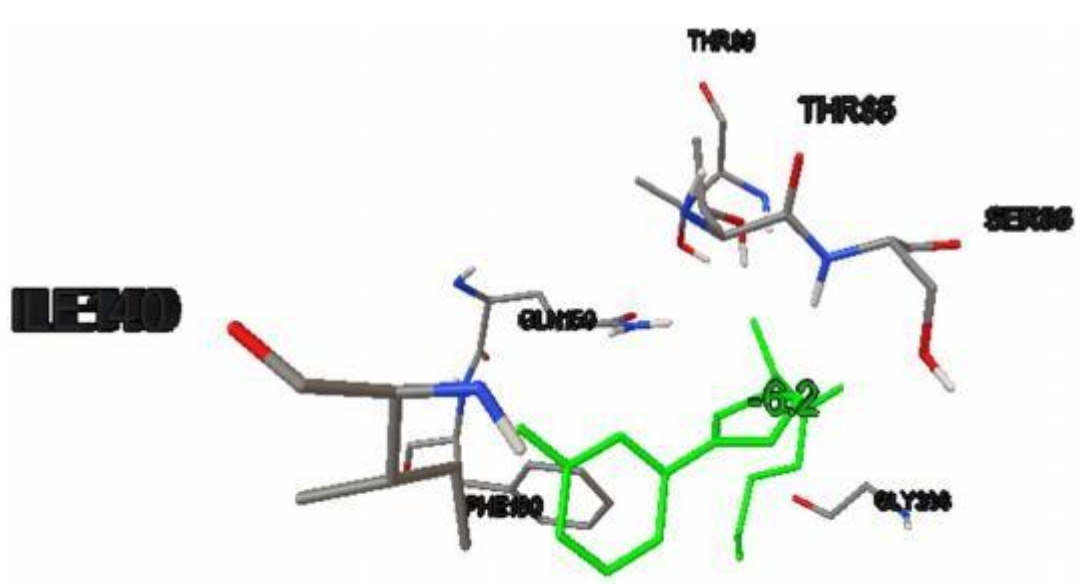

Gambar 4. Interaksi Ligan A1 dengan sisi pengikatan reseptor EHOASS

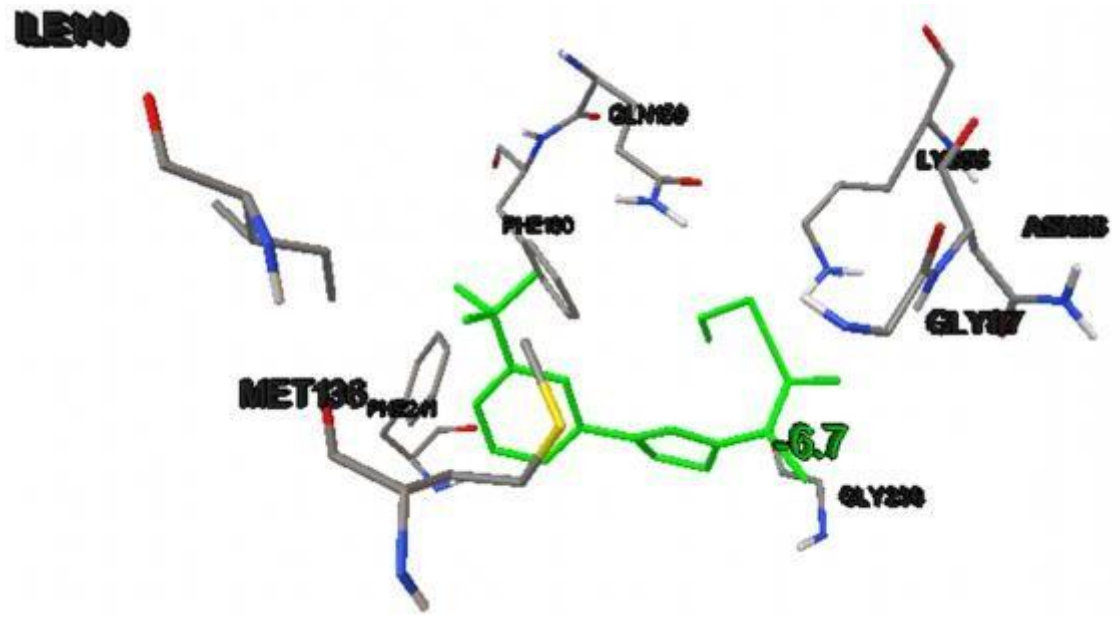

Gambar 5. Interaksi Ligan A4 dengan sisi pengikatan reseptor EHOASS

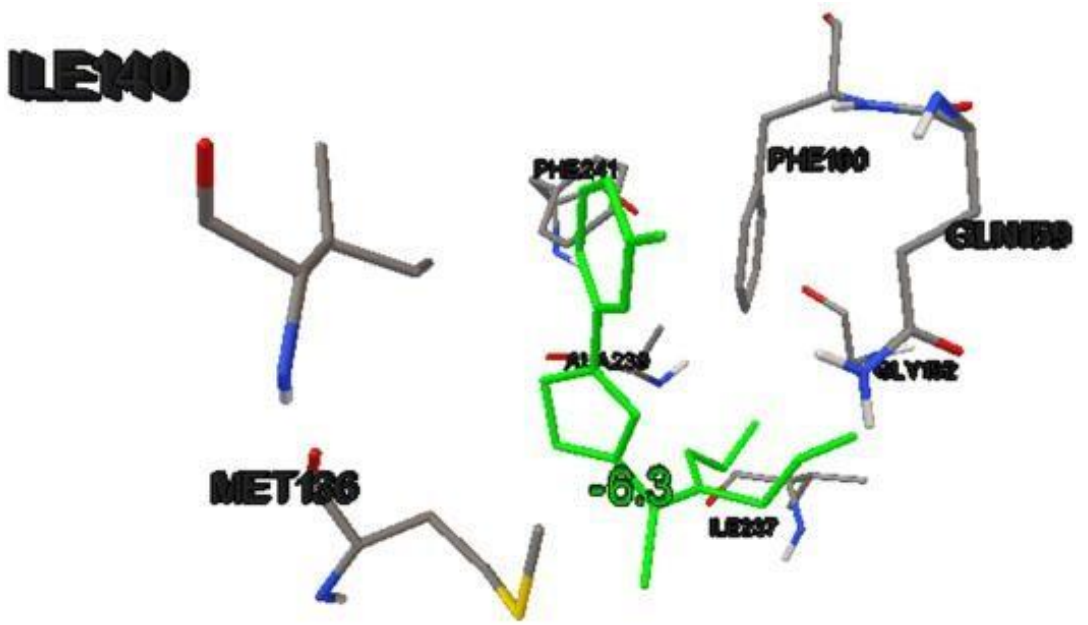

Gambar 6. Interaksi Ligan B1 dengan sisi pengikatan reseptor EHOASS 
La Kilo dkk. / Indo. J. Chem. Res., 2019, 7(1), 9-24

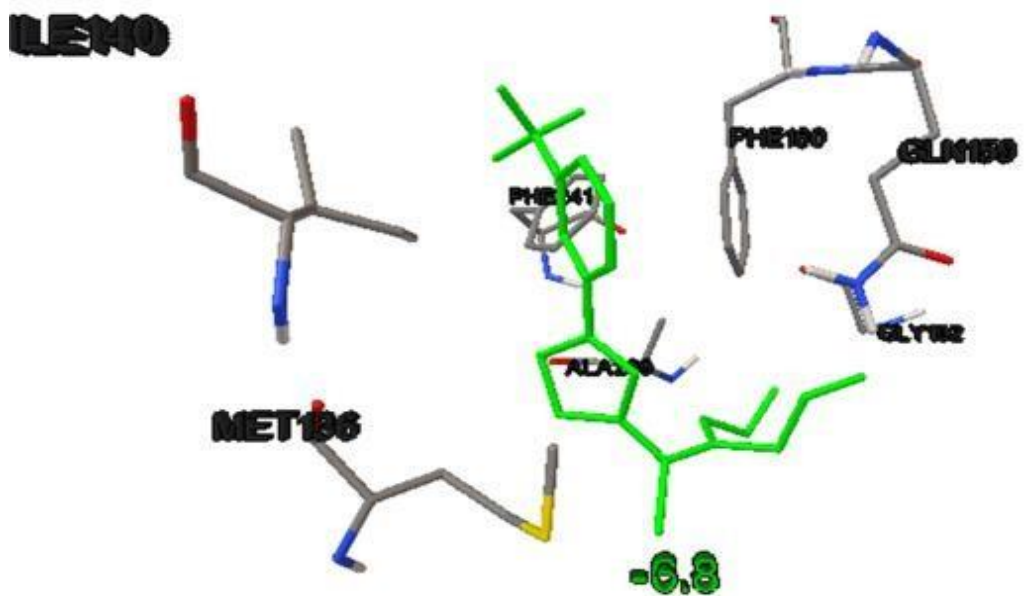

Gambar 7. Interaksi Ligan B4 dengan sisi pengikatan reseptor EHOASS
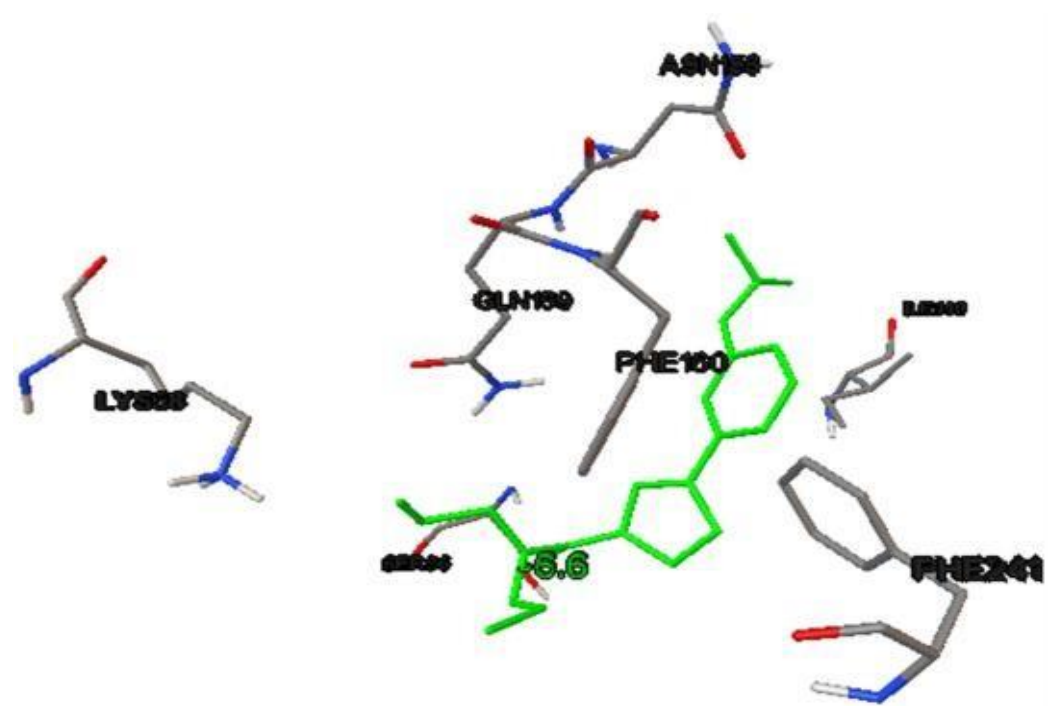

Gambar 8. Interaksi Ligan B9 dengan sisi pengikatan reseptor

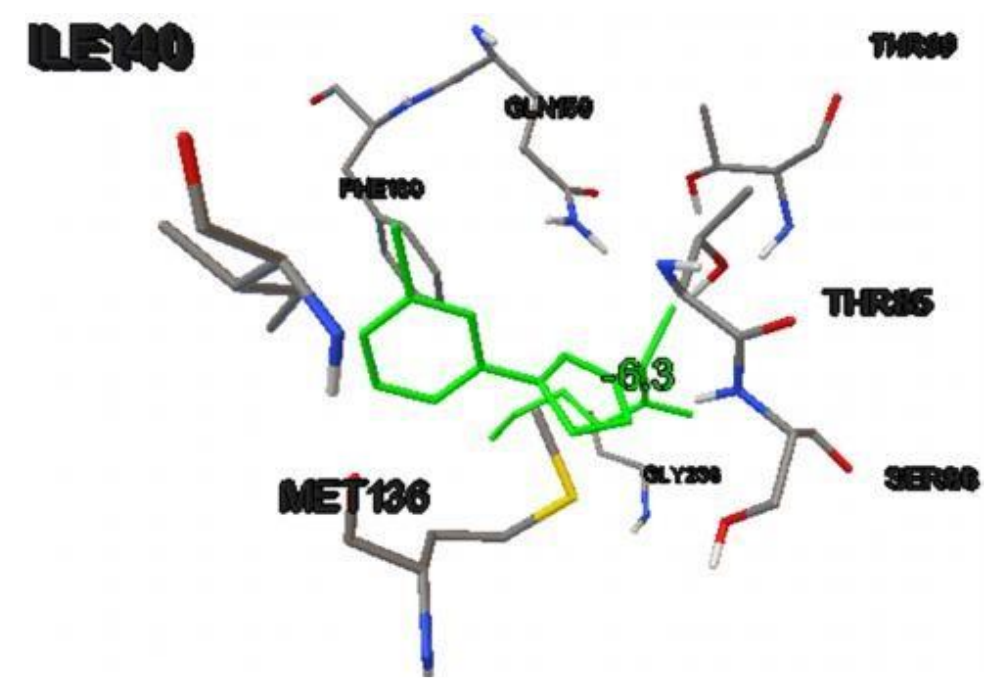

Gambar 9. Interaksi Ligan Penuntun A dengan sisi pengikatan reseptor EHOASS 


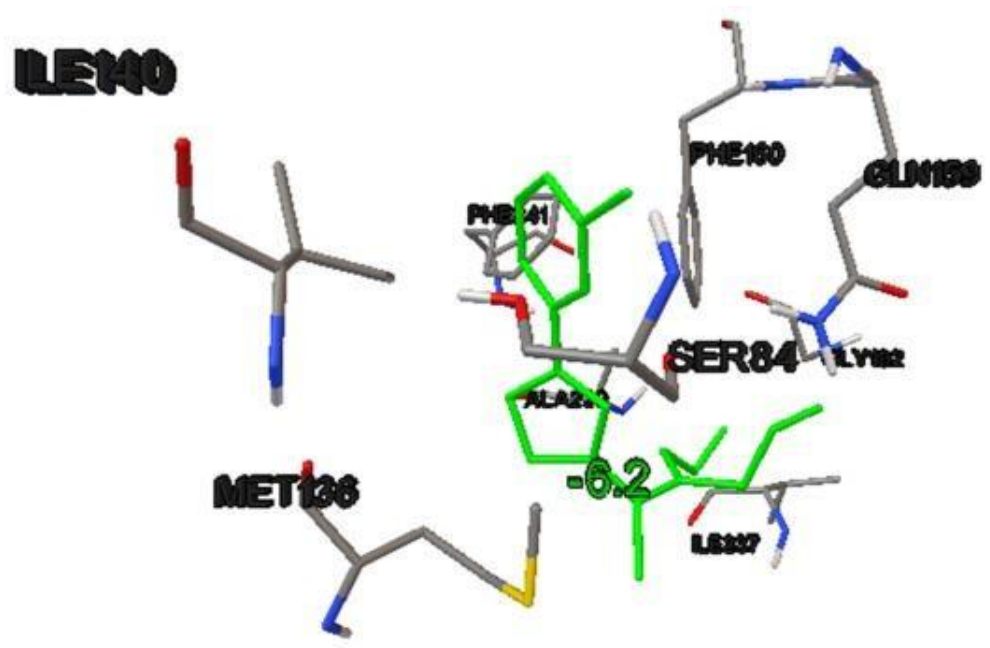

Gambar 10. Interaksi Ligan Penuntun B dengan sisi pengikatan reseptor EHOASS

AutoDock Tools 4.2.6 digunakan untuk melakukan preparasi makromolekul (reseptor) dan ligan, sementara AutoDock Vina digunakan untuk melakukan kalkulasi energi ikatan liganreseptor. Reseptor yang menjadi target docking adalah protein Entamoeba histolytica O-acetylserine sulfhydrylase (EHOASS). Struktur molekul EHOASS diunduh dari situs Protein data bank (PDB) http://www.rcsb.org dengan kode 2PQM seperti yang terlihat pada Gambar 1. Grid box yang digunakan pada makromolekul EHOASS dalam penelitian ini berukuran; $x=18$, $y=18, z=18$, dengan posisi; $x=25,739, y=-$ $1,575, z=96,222$ dan spasi $1 \AA$ sebagaimana ditunjukkan pada Gambar 2.

Hasil penambatan dari perangkat lunak ini adalah energi afinitas ligan-reseptor dan nilai Root Mean Square Deviation (RMSD). Energi Afinitas menunjukkan kekuatan ikatan liganreseptor, semakin besar afinitas maka ikatan ligan-reseptor semakin stabil. RMSD merupakan suatu nilai yg menunjukkan tingkat penyimpangan relatif apabila suatu ligan ditambatkan ke sisi aktif makromolekul. Luaran AutoDock Vina memberikan 2 nilai RMSD, yakni batas atas RMSD (RMSD u.b) dan batas bawah RMSD (RMSD 1.b). Konfigurasi ikatan ligan-reseptor terbaik adalah yang memiliki nilai afinitas terbesar dan nilai RMSD terkecil.

\section{HASIL DAN PEMBAHASAN}

\section{Hasil Perhitungan Deskriptor}

Deskriptor yang dimaksud adalah sifat fisikokimia senyawa turunan pirazolin yang dijadikan sebagai parameter untuk mempelajari hubungan kuantitatif struktur-aktivitas, serta menentukan karakter farmakologis (sifat obat). Data deskriptor inilah yang kemudian dijadikan sebagai variabel bebas pada analisis statistik untuk mencari persamaan HKSA senyawa turunan pirazolin pada penelitian ini. Perhitungan deskriptor ini dilakukan dengan salah satu pendekatan kalkulasi kimia kuantum, yakni Austin Model-1 (AM1). Metode semiempiris AM1 digunakan dalam penelitian ini karena cocok untuk sebagian besar senyawa organik, memiliki ketepatan prediksi yang lebih baik, tidak memerlukan memori yang besar dan waktu yang relatif cepat dalam proses perhitungannya (Tahir dkk., 2004). Hasil perhitungan deskriptor disajikan pada Tabel 1 .

\section{Analisis Statistik}

Statistika yang digunakan untuk menganalisis hubungan kuantitatif struktur senyawa turunan pirazolin dengan aktivitas antiamuba adalah regresi linier berganda atau Multiple Linear regression (MLR). Pada awalnya analisis ini hanya dilakukan terhadap data senyawa training set (tidak semua data). Tujuannya adalah untuk menentukan deskriptor yang berpengaruh signifikan terhadap nilai log $\mathrm{IC}_{50}$ yang terlihat dari persamaan HKSA terbaik yang dihasilkan dari tahap ini. Metode analisis yang digunakan pada SPSS untuk tahap ini adalah metode Backward. Kombinasi berbagai deskriptor disajikan pada Tabel 2. 
La Kilo dkk. / Indo. J. Chem. Res., 2019, 7(1), 9-16

Tabel 1. Hasil perhitungan deskriptor

\begin{tabular}{ccccccccccc}
\hline Seri Senyawa & IC $_{\mathbf{5 0}}$ & AM1_dipole & AM1_IP & TPSA & AM1_HF & MR & AM1_HOMO & AM1_LUMO & Glob & Log P $(\mathbf{o} / \mathbf{w})$ \\
\hline 1 & 14,0 & 5,6691 & 8,2332 & 59,7200 & 91,8172 & 7,3262 & $-8,2332$ & $-0,5120$ & 0,0423 & 3,1020 \\
2 & 8,5 & 6,8398 & 8,3112 & 59,7200 & 97,3082 & 8,0764 & $-8,3112$ & $-0,6902$ & 0,0421 & 3,9370 \\
3 & 8,0 & 6,7158 & 8,3138 & 59,7200 & 85,3892 & 7,8267 & $-8,3138$ & $-0,6731$ & 0,0421 & 3,7310 \\
4 & 23,0 & 5,7535 & 8,0930 & 59,7200 & 98,0543 & 7,2909 & $-8,0930$ & $-0,4843$ & 0,0438 & 2,9500 \\
5 & 15,2 & 6,8673 & 8,1755 & 59,7200 & 103,2209 & 8,0411 & $-8,1755$ & $-0,6661$ & 0,0436 & 3,7850 \\
6 & 12,2 & 6,7300 & 8,1742 & 59,7200 & 91,2164 & 7,7913 & $-8,1742$ & $-0,6455$ & 0,0436 & 3,5790 \\
7 & 23,3 & 5,5910 & 8,2339 & 59,7200 & 85,6932 & 7,7948 & $-8,2339$ & $-0,5079$ & 0,0221 & 3,5440 \\
8 & 14,2 & 6,8041 & 8,3107 & 59,7200 & 91,2340 & 8,5476 & $-8,3107$ & $-0,6979$ & 0,0221 & 4,3790 \\
9 & 12,3 & 6,7107 & 8,3024 & 59,7200 & 79,2400 & 8,2978 & $-8,3024$ & $-0,6798$ & 0,0221 & 4,1730 \\
10 & 11,2 & 5,6225 & 8,2203 & 59,7200 & 87,1878 & 7,7610 & $-8,2203$ & $-0,4892$ & 0,0406 & 3,4600 \\
11 & 6,1 & 6,8895 & 8,2978 & 59,7200 & 92,7981 & 8,5138 & $-8,2978$ & $-0,6888$ & 0,0405 & 4,2950 \\
12 & 5,0 & 6,7550 & 8,2942 & 59,7200 & 80,7596 & 8,2641 & $-8,2942$ & $-0,6650$ & 0,0405 & 4,0890 \\
13 & 5,7 & 5,1303 & 8,2680 & 50,9300 & 93,5876 & 8,2461 & $-8,2680$ & $-0,3765$ & 0,0732 & 3,8120 \\
14 & 2,4 & 6,2917 & 8,3467 & 50,9300 & 98,9283 & 9,0012 & $-8,3467$ & $-0,5683$ & 0,0739 & 4,6470 \\
15 & 0,7 & 6,3595 & 8,3470 & 50,9300 & 87,3646 & 8,7514 & $-8,3470$ & $-0,5641$ & 0,0736 & 4,4410 \\
16 & 4,2 & 4,9350 & 8,2520 & 50,9300 & 102,3560 & 7,7831 & $-8,2520$ & $-0,3373$ & 0,0855 & 3,0970 \\
17 & 1,2 & 6,1557 & 8,3278 & 50,9300 & 107,7825 & 8,5359 & $-8,3278$ & $-0,5426$ & 0,0858 & 3,9320 \\
18 & 1,0 & 5,4069 & 8,3645 & 50,9300 & 95,5778 & 8,2861 & $-8,3645$ & $-0,5028$ & 0,0856 & 3,7260 \\
19 & 2,0 & 5,2501 & 8,2490 & 50,9300 & 89,0347 & 8,7178 & $-8,2490$ & $-0,3565$ & 0,1011 & 4,3250 \\
20 & 0,8 & 5,8684 & 8,3430 & 50,9300 & 93,9324 & 9,4749 & $-8,3430$ & $-0,5346$ & 0,1045 & 5,1600 \\
21 & 0,6 & 6,2169 & 8,3207 & 50,9300 & 82,3808 & 9,2252 & $-8,3207$ & $-0,5212$ & 0,1033 & 4,9540 \\
\hline
\end{tabular}


La Kilo dkk. / Indo. J. Chem. Res., 2019, 7(1), 9-24

Tabel 2. Hasil analisis statistik Training set

\begin{tabular}{|c|c|c|c|c|c|}
\hline No & Kombinasi Deskriptor & $\mathbf{R}$ & $\mathbf{R}^{2}$ & SEE & $\mathbf{F}_{\text {Hitung }}$ \\
\hline 1 & $\begin{array}{l}\text { Log P, AM1_LUMO, AM1_HF, } \\
\text { AM1_HOMO, Glob, TPSA, } \\
\text { AM1_Dipole, MR }\end{array}$ & 0,979 & 0,958 & 0,16348 & 17,322 \\
\hline 2 & $\begin{array}{l}\text { Log P, AM1_LUMO, AM1_HF, } \\
\text { AM1_HOMO, Glob, TPSA, } \\
\text { AM1_Dipole }\end{array}$ & 0,978 & 0,956 & 0,15578 & 21,747 \\
\hline 3 & $\begin{array}{l}\text { Log P, AM1_LUMO, AM1_HF, } \\
\text { AM1_HOMO, Glob, TPSA }\end{array}$ & 0,977 & 0,954 & 0,14829 & 27,953 \\
\hline 4 & $\begin{array}{l}\text { Log P, AM1_LUMO, AM1_HF, } \\
\text { Glob, TPSA, AM1_Dipole }\end{array}$ & 0,976 & 0,953 & 0,14149 & 36,805 \\
\hline
\end{tabular}

Tabel 3. Daftar Substituen dan kode molekul senyawa baru

\begin{tabular}{cccc}
\hline No & Substituen $(\mathbf{X})$ & \multicolumn{2}{c}{ Kode Senyawa baru } \\
\hline 1 & $\mathrm{~F}$ & $\mathrm{~A} 1$ & $\mathrm{~B} 1$ \\
2 & $\mathrm{I}$ & $\mathrm{A} 2$ & $\mathrm{~B} 2$ \\
3 & $\mathrm{CH}_{3}$ & $\mathrm{~A} 3$ & $\mathrm{~B} 3$ \\
4 & $\mathrm{CF}_{3}$ & $\mathrm{~A} 4$ & $\mathrm{~B} 4$ \\
5 & $\mathrm{NO}_{2}$ & A5 & B5 \\
6 & $\mathrm{~N}_{2}\left(\mathrm{CH}_{3}\right)_{2}$ & A6 & B6 \\
7 & $\mathrm{OCH}_{3}$ & A7 & B7 \\
8 & $\mathrm{OH}$ & A8 & B8 \\
9 & $\mathrm{OCH}\left(\mathrm{CH}_{3}\right)_{2}$ & A9 & B9 \\
\hline
\end{tabular}

Tabel 4. Senyawa baru Antiamuba

Kode Senyawa


La Kilo dkk. / Indo. J. Chem. Res., 2019, 7(1), 9-24

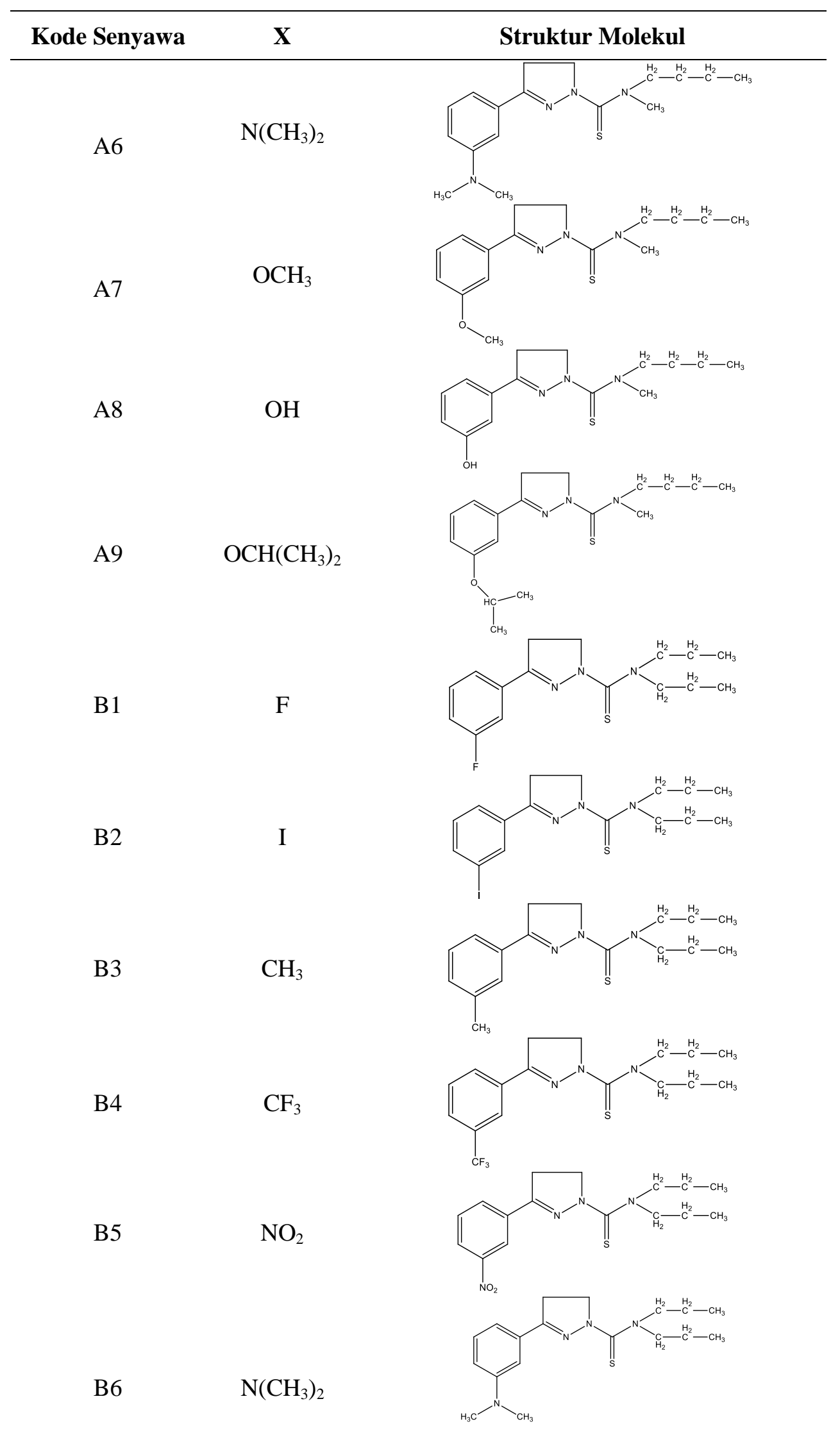


La Kilo dkk. / Indo. J. Chem. Res., 2019, 7(1), 9-24

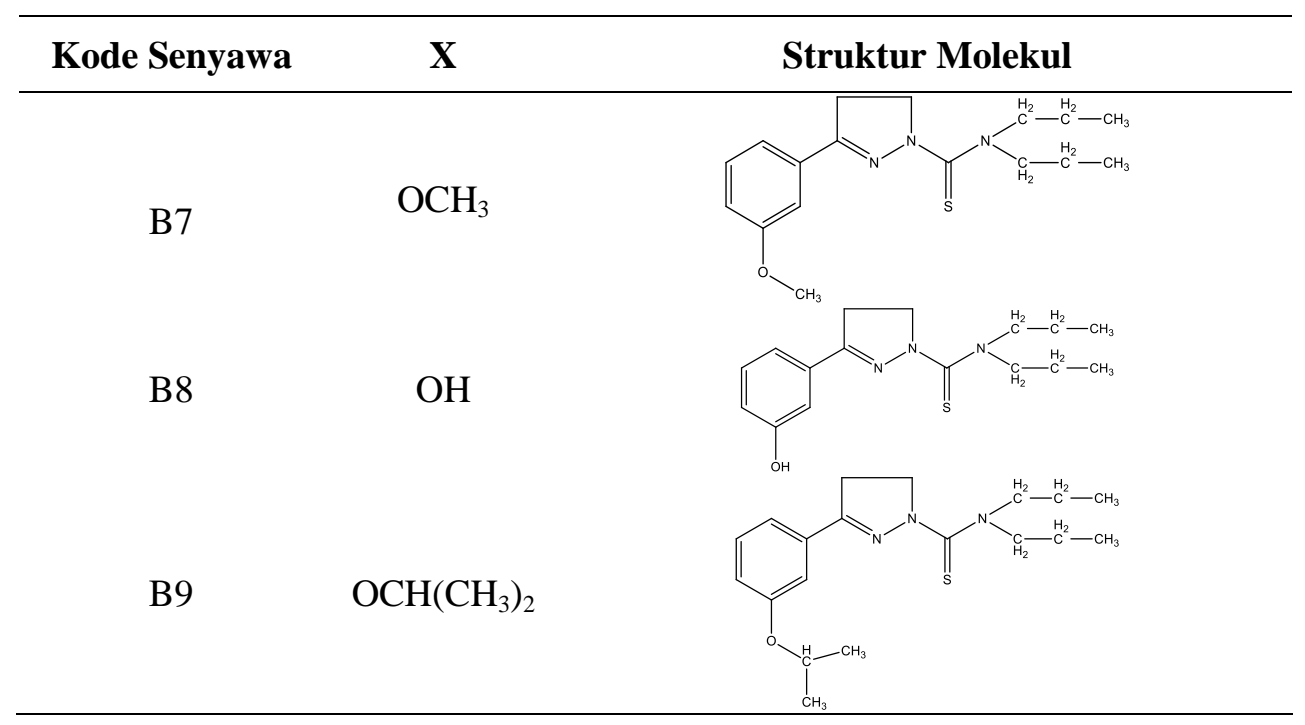

Sebelumnya dilakukan pemisahan terhadap 21 senyawa turunan pirazolin menjadi Training set dan test set. Senyawa training set dianalisis untuk meghasilkan model persamaan HKSA, sedangkan test set digunakan untuk memvalidasi model persamaan HKSA yang dihasilkan dari training set. Senyawa test set yang digunakan adalah 6 senyawa yang ditentukan dengan memilih 2 senyawa dengan nilai $\log \mathrm{IC}_{50}$ terkecil, 2 senyawa dengan nilai $\log \mathrm{IC}_{50}$ menengah dan 2 senyawa dengan nilai $\log \mathrm{IC}_{50}$ terbesar. Sisanya 15 senyawa dijadikan sebagai senyawa training set.

Menurut La Kilo (2014), penentuan persamaan HKSA terbaik adalah dengan melihat kriteria berikut; 1) Nilai $\mathrm{R}^{2}$ lebih besar dari 0,6., 2) Nilai SEE kurang dari 0,3., dan 3) Nilai $\mathrm{F}_{\text {hitung }} / \mathrm{F}_{\text {Tabel }}$ lebih besar atau sama dengan 1 . Tabel 1 menunjukkan bahwa 4 persamaan HKSA yang dihasilkan dari analisis MLR memiliki nilai $\mathrm{R}^{2}$ lebih besar dari 0,6 (memenuhi kriteria), yakni 0,95 . Hal ini mengGambarkan pengaruh variabel bebas (deskriptor) terhadap variabel terikat (aktivitas biologis) sangat besar, yakni $95 \%$. Nilai SEE semua persamaan tersebut kurang dari 0,3 (memenuhi kriteria), yakni 0,1. Nilai ini menunjukkan bahwa tingkat kesalahan persamaan tersebut dalam menghitung nilai variabel terikat sangat kecil (mendekati 0). Persamaan tersebut memiliki akurasi yang sangat baik dalam memprediksi nilai aktivitas biologis senyawa turunan Pirazolin. Kriteria berikut adalah parameter nilai rasio $\mathrm{F}_{\text {hitung }} / \mathrm{F}_{\text {Tabel }}$ yang menunjukkan tingkat signifikansi pengaruh deskriptor terhadap aktivitas biologis.
Hasil kalkulasi nilai $\mathrm{F}_{\text {hitung }} / \mathrm{F}_{\text {Tabel }}$ persamaan 1 sampai 4 adalah lebih besar dari 1 , hal ini berarti bentuk kombinasi deskriptor pada semua persamaan tersebut memiliki pengaruh yang sangat signifikan terhadap aktivitas biologis. Berdasarkan hal ini, disimpulkan bahwa keempat persamaan tersebut memenuhi ketentuan parameter statistik yang telah disebutkan sebelumnya. Dengan demikian, keempat persamaan ini diterima dan divalidasi pada tahap selanjutnya.

\section{Validasi Persamaan HKSA}

Validasi model persamaan HKSA bertujuan untuk memastikan apakah suatu persamaan mampu memprediksikan (menghitung) nilai aktivitas biologis suatu seri senyawa dengan kemungkinan kesalahan yang sekecil mungkin. Ketika model persamaan HKSA valid, maka persamaan tersebut dapat merepresentasikan hubungan kuantitatif antara deksriptor dan aktivitas biologis secara matematis. Validasi model persamaan HKSA dilakukan terhadap senyawa test set dengan menghitung nilai Predicted Residual Sum of Squares (PRESS) dari persamaan yang diterima. Nilai PRESS merupakan jumlah kuadrat selisih nilai aktivitas biologis hasil eksperimen dengan aktivitas biologis prediksi berdasarkan model-model persamaan terpilih. Nilai PRESS yang kecil menunjukkan bahwa persamaan tersebut semakin baik, karena memiliki tingkat kesalahan yang kecil dalam menghitung nilai aktivitas biologis. 
Nilai PRESS terkecil ditunjukkan oleh persamaan 3, yaitu sebesar 0,2632. Dengan demikian persamaan 3 yang melibatkan deskriptor Log P, AM1_LUMO, AM1_HF, AM1_HOMO, Glob, TPSA merupakan persamaan terbaik. Persamaan 3 menunjukkan bahwa deskriptor yang berpengaruh signifikan tehadap aktivitas Antiamuba senyawa turunan Pirazolin adalah Koefisien partisi $(\log \mathrm{P})$, Energi LUMO, Energi HOMO, Kalor pembentukan (HF), Globularitas (Glob) dan total daerah permukaan polar (TPSA).

Selanjutnya deskriptor-deskriptor ini digunakan untuk menganalisa persamaan regresi linier semua data senyawa turunan pirazolin (gabungan training set dan test set). Analisis ini dilakukan untuk menghasilkan persamaan HKSA seri senyawa turunan Pirazolin. Metode analisis regresi yang digunakan pada program SPSS untuk tahap ini adalah metode Enter. Persamaan yang dihasilkan untuk keseluruhan data (21 senyawa) dengan melibatkan deskriptor Log $\mathrm{P}$, AM1_LUMO, AM1_HF, AM1_HOMO, Glob, TPSA adalah sebagai berikut:

$$
\begin{aligned}
& \log \mathrm{IC}_{50}= \mathbf{0 , 8 6 9}+(0,081 \times \text { TPSA })+(0,018 \times \\
&\text { HF })+(0,527 \times \text { E-HOMO })+(3,378 \\
& \text { x E-LUMO }+(-16,938 \times \text { Glob })+ \\
&(0,234 \times \text { Log P })
\end{aligned}
$$

dengan $\mathrm{n}=21 ; \mathrm{R}^{2}=0,9333 ;$ SEE $=0,14558$; $\mathrm{F}_{\text {Hitung }} / \mathrm{F}_{\text {Tabel }}=8,607 ;$ PRESS $=0,491$.

\section{Rancangan Senyawa Baru Antiamuba}

Senyawa penuntun yang digunakan adalah 2 senyawa yang memiliki nilai $\mathrm{IC}_{50}$ terkecil (aktivitas Antiamuba terbaik), yakni senyawa 15 $\left(\mathrm{IC}_{50}=0,7\right)$ dan senyawa $21\left(\mathrm{IC}_{50}=0,6\right)$. Struktur molekul kedua senyawa penuntun ini dapat dilihat pada Gambar 3.

Metode Topliss merupakan metode modifikasi molekul yang menggunakan prinsip dasar pendekatan hubungan struktur aktivitas model Hansch untuk memodifikasi struktur molekul senyawa penuntun yang sudah diketahui aktivitasnya. Modifikasi struktur dengan metode ini adalah memasukkan gugus-gugus yang mempunyai sifat lipofilik, elektronik dan sterik tertentu pada posisi yang memberikan aktivitas lebih tinggi, sama atau lebih rendah dibanding aktivitas senyawa penuntun (Siswandono dan Soekardjo, 2000).
Substituen baru yang digunakan dalam perancangan senyawa usulan ini terangkum pada Tabel 3. Dalam hal ini senyawa usulan dengan kode A berasal dari penuntun 15 dan yang berkode B berasal dari penuntun 21. Sementara daftar senyawa baru hasil rancangan dapat dilihat pada Tabel 4.

Perhitungan deskriptor molekul dilakukan dengan cara membuat data base terebih dahulu. Kemudian dilakukan perhitungan deskriptor setiap molekul untuk melengkapi data base. Perhitungan dilakukan dengan menggunakan fitur - QuaSAR-Descriptor pada MOE. Deskriptor yang dihitung pada tahap ini adalah deskriptor-deskriptor yang berpengaruh (berdasarkan persamaan HKSA), yakni Koefisien partisi (Log P), Energi LUMO, Energi HOMO, Kalor pembentukan (HF), Globularitas (Glob) dan total daerah permukaan polar (TPSA).

Selanjutnya nilai $\log \mathrm{IC}_{50}$ prediksi senyawa baru dihitung menggunakan persamaan HKSA seri senyawa turunan Pirazolin yang telah diperoleh sebelumnya. Nilai $\log \mathrm{IC}_{50}$ ini kemudian dikonversi menjadi $\mathrm{IC}_{50}$ dengan rumus antilog menggunakan program MS Excel. Hasil yang diperoleh terangkum pada Tabel 5. Dari Tabel 5 dapat dilihat bahwa senyawa usulan memiliki nilai $\mathrm{IC}_{50}$ yang bervariasi. Senyawa usulan yang memiliki aktivitas lebih baik dari senyawa penuntun adalah yang memiliki nilai $\mathrm{IC}_{50}$ yang lebih kecil. Dengan demikian, diperoleh 5 senyawa baru yang memiliki nilai aktivitas Antiamuba yang lebih baik dari senyawa penuntun, yakni senyawa $\mathrm{A} 1\left(\mathrm{IC}_{50}=\right.$ $0,28)$, senyawa $\mathrm{A} 4\left(\mathrm{IC}_{50}=0,0028\right)$, senyawa $\mathrm{B} 1$ $\left(\mathrm{IC}_{50}=0,13\right)$, senyawa $\mathrm{B} 4\left(\mathrm{IC}_{50}=0,001\right)$ dan senyawa B9 $\left(\mathrm{IC}_{50}=0,49\right)$. Senyawa-senyawa inilah yang dijadikan bahan kajian pada studi molecular docking untuk dipelajari interaksinya dengan reseptor EHOASS. Kelima senyawa usulan terbaik ini dipaparkan dalam Tabel 6.

\section{Kajian HKSA}

Hasil kajian HKSA menunjukkan bahwa deskriptor yang mempengaruhi aktivitas Antiamuba seri senyawa turunan pirazolin tersubstitusi 1-N dari tiosemikarbazon adalah koefisien partisi $(\log \mathrm{P})$, Energi LUMO, Energi HOMO, Kalor pembentukan (HF), Globularitas (Glob) dan total daerah permukaan polar (TPSA). 
Tabel 5. Nilai $\mathrm{IC}_{50}$ prediksi senyawa baru

\begin{tabular}{ccc}
\hline Senyawa & Log IC50 Pred & IC50 Pred \\
\hline A1 & $-0,5418886$ & 0,28 \\
A2 & 0,4020493 & 2,52 \\
A3 & 0,7961692 & 6,25 \\
A4 & $-2,5411816$ & 0,0028 \\
A5 & 0,5399945 & 3,46 \\
A6 & 1,4584295 & 28,73 \\
A7 & $-23,7667292$ & 1,71 \\
A8 & 0,461508 & 2,89 \\
A9 & 0,5327962 & 3,41 \\
B1 & $-0,8543696$ & 0,13 \\
B2 & 0,193749 & 1,56 \\
B3 & 0,3420498 & 2,19 \\
B4 & $-2,9793962$ & 0,001 \\
B5 & 0,3278256 & 2,12 \\
B6 & 1,003475 & 10,08 \\
B7 & $-0,1553113$ & 0,69 \\
B8 & 0,1421558 & 1,38 \\
B9 & $-0,3034286$ & 0,49 \\
\hline
\end{tabular}

Koefisien partisi merupakan salah satu parameter hidrofobik/lipofilik yang menunjukkan kondisi keberadaan molekul obat pada pelarut nonpolar dan polar. Nilai koefisien partisi yang terlalu besar akan menyebabkan molekul obat tertahan lama pada lipid, sehingga tidak akan mampu mencapai target. Sebaliknya nilai koefisien partisi yang terlalu kecil akan menyebabkan molekul obat sangat larut dalam air (darah), sehingga tidak akan mampu menembus sawar (barrier) lipid untuk mencapai organ lipid seperti otak dan jaringan saraf lain (Nogrady, 1992).

Energi HOMO (Highest Occupied Molecular Orbital) dan energi LUMO (Lowest Unoccupied Molecular Orbital) merupakan parameter elektronik yang turut menentukan aktivitas obat. Energi HOMO ( $\left.\mathrm{E}_{\text {Номо }}\right)$ menunjukkan kemampuan suatu molekul untuk mendonorkan elektron ke akseptor yang memiliki orbital molekul kosong. Sedangkan Energi LUMO ( $\left.\mathrm{E}_{\text {LUMO }}\right)$ mengGambarkan kemampuan molekul untuk menerima elektron. Molekul dengan nilai $\mathrm{E}_{\text {НОМо }}$ tinggi memiliki kemampuan yang tinggi untuk mendonorkan elektron dan akan cenderung lebih reaktif. Sementara molekul dengan nilai $\mathrm{E}_{\mathrm{LUMO}}$ rendah memiliki kemampuan yang sangat baik sebagai akseptor elektron dibandingkan molekul dengan nilai $\mathrm{E}_{\mathrm{LUMO}}$ yang lebih tinggi (Verma dan Hansch, 2011).

Kalor pembentukan berkaitan dengan arah proses suatu reaksi apakah berlangsung spontan atau tidak spontan. Suatu reaksi kimia berlangsung secara spontan apabila $\Delta \mathrm{H}<0$ dan berlangsung tidak spontan apabila $\Delta \mathrm{H}>0$ (Nogrady, 1992).

Globularitas berhubungan dengan kelarutan senyawa dalam air. Senyawa yang memiliki bentuk globularitas merupakan senyawa yang berbentuk bola. Bentuk ini dapat meningkatkan kelarutan senyawa dalam air dengan menempatkan gugus polar atom pada permukaan senyawa (di mana gugus-gugus ini dapat berpartisipasi dalam interaksi menarik dengan molekul air). Hal ini terutama disebabkan oleh interaksi dari atom-atom dalam molekul. Sifat kelarutan dalam air dari senyawa globular memungkinkan senyawa tersebut untuk berada dalam cairan biologis sebagai molekul individu atau dalam kelompok kecil dan untuk mencapai berbagai fungsi biologis penting (Rembet, 2011).

Daerah Permukaan Polar molekul adalah parameter yang sangat berguna untuk memperkirakan sifat transport obat. Daerah Permukaan Polar didefinisikan sebagai jumlah permukaan atom-atom polar (umumnya oksigen, nitrogen dan Hidrogen yang berdempetan) dalam molekul. Parameter ini menunjukkan korelasi dengan absorpsi usus manusia dan penetrasi sawar darah-otak (Iyyappan dkk., 2010).

Deskriptor-deskriptor tersebut bergantung pada subtituen $(\mathrm{x})$ yang tersubtitusi pada cincin aromatik senyawa turunan Pirazolin. Sehingga perancangan senyawa baru dilakukan melalui pendekatan Topliss dengan mengganti subtituen $\mathrm{Cl}$ senyawa penuntun. Berdasarkan hasil kalkulasi nilai $\mathrm{IC}_{50} 18$ senyawa baru menggunakan persamaan HKSA, diperoleh 5 senyawa yang memiliki aktivitas biologis yang lebih baik dari senyawa penuntun (penuntun $\mathrm{A}$ dan B), yakni senyawa A1, A4, B1, B4 dan B9. Aktivitas biologis yang lebih baik ini tentunya dipengaruhi oleh sifat fisikokimia (deskriptor) yang berkontribusi signifikan. Nilai deskriptor kelima senyawa usulan terbaik ini terangkum pada Tabel 7. 
La Kilo dkk. / Indo. J. Chem. Res., 2019, 7(1), 9-16

Tabel 6. Rancangan senyawa baru dengan aktivitas prediksi yang lebih

\begin{tabular}{ll}
\hline Senyawa & (hasil eksperimen) \\
(Prediksi)
\end{tabular}

Tabel 7. Nilai deskriptor senyawa rancangan baru (A1, A4, B1, B4, B9), Penuntun A dan B

\begin{tabular}{|c|c|c|c|c|c|c|c|}
\hline \multirow{3}{*}{ Senyawa } & \multicolumn{7}{|c|}{ Penuntun $\mathrm{A}$ dan $\mathrm{B}$} \\
\hline & \multicolumn{7}{|c|}{ Deskriptor } \\
\hline & HF & $\mathbf{E}_{\text {номо }}$ & $\mathbf{E}_{\text {Lumo }}$ & TPSA & Glob & $\log P$ & BM \\
\hline A1 & $49,431 \mathrm{C}$ & $-8,3605$ & $-0,5979$ & 50,93 & 0,0725 & 4,002 & 293,41 \\
\hline A4 & $\begin{array}{c}- \\
61,5552\end{array}$ & $-8,4354$ & $-0,7978$ & 50,93 & 0,069 & 4,7838 & 343,417 \\
\hline B1 & 44,0575 & $-8,3336$ & $-0,5455$ & 50,93 & 0,1013 & 4,515 & 307,437 \\
\hline B4 & 66,4515 & $-8,4011$ & $-0,7666$ & 50,93 & 0,1043 & 5,2968 & 357,444 \\
\hline B9 & 45,8904 & $-8,2727$ & $-0,3688$ & 60,16 & 0,1268 & 5,121 & 347,527 \\
\hline Penuntun A & $87,364 \epsilon$ & $-8,3470$ & $-0,5641$ & 50,93 & 0,0736 & 4,4410 & 309,865 \\
\hline Penuntun B & $82,380 \varepsilon$ & $-8,3207$ & $-0,5212$ & 50,93 & 0,1033 & 4,9540 & 323,892 \\
\hline
\end{tabular}


Lipinski dkk. (2001) telah menganalisa lebih dari 2000 senyawa obat dalam uji klinis dan menyimpulkan bahwa suatu senyawa obat akan memiliki absorpsi atau permeasi yang baik jika (1) berat molekul kurang dari $500 \mathrm{Da}$ (2) nilai $\log \mathrm{P}$ kurang dari 5, (3) jumlah donor ikatan hidrogen kurang dari 5, dan (4) jumlah akseptor ikatan hidrogen kurang dari 10 Aturan Lipinski dapat menentukan sifat fisikokimia ligan untuk menentukan karakter hidrofobik/hidrofilik suatu senyawa untuk melalu membran sel oleh difusi pasif. Aturan ini kemudian disebut "Lipinski Rule of Five" (Lipinski dkk., 2001).

Berat molekul yang lebih dari $500 \mathrm{Da}$ tidak dapat berdifusi menembus membrane sel. Nilai Log P yang lebih besar dari 5 akan menyebabkan senyawa obat akan cenderung memiliki tingkat toksisitas yang tinggi karena akan tertahan lebih lama pada lipid bilayer dan terdistribusi lebih luas di dalam tubuh sehingga selektifitas ikatan terhadap enzim target menjadi berkurang. Nilai Log $\mathrm{P}$ yang terlalu negatif juga tidak baik karena jika molekul tersebut tidak dapat melewati membran lipid bilayer. Jumlah donor dan akseptor ikatan hidrogen mendeskripsikan semakin tinggi kapasitas ikatan hidrogen, maka semakin tinggi energi yang dibutuhkan agar proses absorpsi dapat terjadi. Secara umum aturan Lipinski mengGambarkan solubilitas senyawa tertentu untuk menembus membran sel oleh difusi pasif (Syahputra dkk., 2011).

Tabel 6 menunujukkan bahwa senyawa usulan A1, A4 dan B1 memiliki nilai Log P kurang dari 5, sementara senyawa usulan B4 dan B9 memiliki nilai $\log \mathrm{P}$ lebih dari 5. Dengan demikian, walaupun senyawa B4 memiliki aktivitas Antiamuba yang lebih baik diantara semua senyawa usulan, tetapi toksisitasnya perlu diwaspadai. Hal ini membutuhkan pengujian klinis untuk membuktikan sifat toksik dari senyawa B4 tersebut. Dari Tabel 6 juga terlihat bahwa kelima senyawa usulan memiliki karakteristik nonpolar yang serupa, karena memiliki nilai TPSA yang sama. Karakteristik inilah yang tentunya mempengaruhi bentuk interaksi dengan reseptor. Globularitas senyawa usulan menyerupai senyawa penuntunnya masingmasing, yakni senyawa A1 dan A4 serupa dengan senyawa penuntun $\mathrm{A}$, sedangkan senyawa B1, B4 dan B9 serupa dengan senyawa penuntun B. Sifat ini dipengaruhi oleh kemiripan struktur antara senyawasenyawa tersebut. Masing-masing senyawa usulan tersebut memiliki rantai alifatik yang sama dengan penuntunnya, hanya saja berbeda pada subtituen. Subtituen kelima senyawa usulan tersebut adalah $\mathrm{F}, \mathrm{CH}_{3}$ dan $\mathrm{OCH}\left(\mathrm{CH}_{3}\right)_{2}$, sedangkan subtituen senyawa penuntun adalah $\mathrm{Cl}$. Keempat subtituen ini merupakan subtituen yang isosterik, yakni merupakan kelompok atom/senyawa yang memiliki sifat fisikokimia serupa. Jenis rantai alifatik yang sama dan subtituen yang isosteric inilah yang menyebabkan kesamaan sifat globularitas.

Sifat lain yang terlihat pada Tabel 6 adalah kalor pembentukan (HF) dan energi HOMO-LUMO. Nilai HF yang sangat berbeda dimiliki oleh senyawa usulan A4 dan B4, yakni bernilai negatif (-). Energi HOMOLUMO kelima senyawa usulan tidak jauh berbeda dari senyawa penuntun. Hanya saja, senyawa $\mathrm{A} 4$ dan $\mathrm{B} 4$ memiliki nilai $\mathrm{E}_{\mathrm{LUMO}}$ yang sedikit lebih negative senyawa penuntun maupun usulan lainnya pada tabel tersebut.

\section{Interaksi Senyawa Baru dengan Reseptor}

Ligan yang digunakan pada studi penambatan molekul dalam penelitan ini berjumlah 7 senyawa, yakni 2 senyawa penuntun (penuntun A dan B) dan 5 senyawa usulan yang memiliki aktivitas Antiamuba terbaik (A1, A4, B1, B4 dan B9). Penambatan senyawa penuntun dilakukan sebagai bahan pembanding terhadap senyawa usulan.

Prosedur penambatan diawali dengan tahap preparasi makromolekul dan ligan. Keseluruhan tahap preparasi ini dilakukan dengan menggunakan aplikasi AutoDock Tools 4.2.6. Tahap ini meliputi penghilangan molekul air pada EHOASS, penentuan Grid box binding site, serta penentuan bagian ligan yang dapat dirotasi untuk pencarian konformasi terbaik. Penghilangan molekul air pada EHOASS bertujuan untuk mengurangi efek sterik yang ditimbulkan molekul air terhadap ligan ketika akan berinteraksi dengan binding site EHOASS. Binding site merupakan sisi aktif dari makromolekul yang 
memungkinkan terjadinya interaksi dengan ligan. Grid box didefinisikan sebagai dimensi sisi aktif makromolekul berupa kubus yang memiliki ukuran dan posisi tertentu untuk ruang penambatan ligan. Ukuran dan posisi Grid box direpresentasikan dengan koordinat $\mathrm{x}, \mathrm{y}$ dan $\mathrm{z}$ yang diatur dengan spasi (jarak) tertentu. Ukuran dan posisi yang digunakan pada penelitian ini merujuk pada penelitian Nagpal dkk. (2012) yang melakukan virtual screening inhibitor enzim O-Acetyl-L-Serine Sulfhydrylase Entamoeba histolytica dengan letak sisi aktif yang serupa. Pada sisi aktif ini terdapat beberapa residu Asam Amino yang terlibat dalam interaksi dengan ligan, yakni Val 57, Ser 84, Thr 85, Ser 86, Gly 87, Asn 88, Thr 89, Gly 90, Met 112, Ser 113, Arg 116, Gln 159, Phe 160, Gly 192, Thr 193, His 232, Gly 233, Ile 234, Gln 235, Gly 236, Ile 237, Gly 238, Ala 239, Phe 241, Tyr 313, Thr 316 dan Lys-58.

Hasil penambatan menunjukkan bahwa semua senyawa baru mampu melakukan interaksi spesifik pada sisi pengikatan reseptor EHOASS dengan baik. Hal ini ditunjukkan oleh nilai afinitas ikatan yang lebih baik dibandingkan senyawa penuntun. Ligan A1 berinteraksi dengan residu (sisi pengikatan) EHOASS melalui ikatan Van der Waals. Pada hal ini residu EHOASS yang berinteraksi dengan ligan A1 adalah Thr85, Ser86, Tyr89, Gln159, Phe160, Gly236 sebagaimana ditunjukkan pada Gambar 4. Energi afinitas interaksi ini adalah $-6,2 \mathrm{kkal} / \mathrm{mol}$, artinya dibutuhkan energi sebesar $6,2 \mathrm{kkal} / \mathrm{mol}$ untuk memutuskan ikatan ligan A1 dengan reseptor EHOASS. Ligan A4 berinteraksi dengan residu (sisi pengikatan) EHOASS melalui ikatan Van der Waals. Residu EHOASS yang berinteraksi dengan ligan A4 adalah Lys58, Gly87, Asn88, Met136, Ile140, Gln159, Phe160, Phe241 sebagaimana ditunjukkan pada Gambar 5. Energi afinitas interaksi ini adalah $-6,7 \mathrm{kkal} / \mathrm{mol}$, artinya dibutuhkan energi sebesar 6,7 $\mathrm{kkal} / \mathrm{mol}$ untuk memutuskan ikatan ligan A4 dengan reseptor EHOASS.

Ligan B1 berinteraksi dengan residu (sisi pengikatan) EHOASS melalui ikatan Van der Waals. Residu EHOASS yang berinteraksi dengan ligan B1 adalah Met136, Gln159, Phe160, Gly192, Ile237, Ala239, Phe241 sebagaimana ditunjukkan pada Gambar 6 . Energi afini tas interaksi ini adalah -6,3 $\mathrm{kkal} / \mathrm{mol}$, artinya dibutuhkan energi sebesar $6,3 \mathrm{kkal} / \mathrm{mol}$ untuk memutuskan ikatan ligan B1 dengan reseptor EHOASS. Ligan B4 berinteraksi dengan residu (sisi pengikatan) EHOASS melalui ikatan Van der Waals. Residu EHOASS yang berinteraksi dengan ligan B4 adalah Met136, Ile140, Gln159, Phe160, Gly192, Ala239, Phe241 sebagaimana ditunjukkan pada Gambar 7. Energi afinitas interaksi ini adalah $-6,8 \mathrm{kkal} / \mathrm{mol}$, artinya dibutuhkan energi sebesar $6,8 \mathrm{kkal} / \mathrm{mol}$ untuk memutuskan ikatan ligan B4 dengan reseptor EHOASS. Ligan B9 berinteraksi dengan residu (sisi pengikatan) EHOASS melalui ikatan Van der Waals. Residu EHOASS yang berinteraksi dengan ligan B9 adalah Lys58, Ile140, Asn158, Gln159, Phe160, Phe241 sebagaimana ditunjukkan pada Gambar 8 . Energi afinitas interaksi ini adalah $-6,6$ $\mathrm{kkal} / \mathrm{mol}$, artinya dibutuhkan energi sebesar $6,6 \mathrm{kkal} / \mathrm{mol}$ untuk memutuskan ikatan ligan B9 dengan reseptor EHOASS.

Senyawa penuntun A dan B melakukan interaksi dengan reseptor EHOASS melalui ikatan Van der Waals sebagaimana kelima senyawa usulan. Hal ini karena kemiripan struktur dan sifat fisikokimia senyawa penuntun dan senyawa usulan sebagaimana telah dijelaskan sebelumnya. Interaksi senyawa Penuntun A dengan reseptor EHOASS terjadi pada residu Thr85, Ser86, Thr89, Gln159, Phe160, Met136, Gly236 dengan energi afinitas sebesar $-6,3 \mathrm{kkal} / \mathrm{mol}$ sebagaimana ditunjukkan pada Gambar 9. Sementara interaksi senyawa Penuntun B dengan reseptor EHOASS terjadi pada residu Ser84, Met136, Ile140, Gln159, Phe160, Gly192, Phe241, Ile237, Ala239 dengan energi afinitas sebesar $-6,2 \mathrm{kkal} / \mathrm{mol}$ sebagaimana ditunjukkan pada Gambar 10.

Interaksi yang terjadi antara senyawa penuntun dengan reseptor maupun antara senyawa usulan dengan reseptor adalah ikatan Van der Waals. Ikatan Van der Waals interaksi antara atom atau molekul yang tidak bermuatan dan letaknya berdekatan. Interaksi ini terjadi antara cincin benzena atau dengan reseptor rantai hidrokarbon dengan reseptor. Sebagaimana yang ditunjukkan, bahwa senyawa penuntun dan senyawa usulan (A1, 
A4, B1, B4 dan B9) memiliki cincin benzen dan juga rantai alifatik (hidrokarbon). Hal inilah yang menyebabkan terjadinya interaksi van der waals. Tidak adanya ikatan Hidrogen dikarenakan ligan (senyawa penuntun dan senyawa usulan) tidak memiliki gugus yang potensial untuk membentuk ikatan hidrogen dengan reseptor.

\section{KESIMPULAN}

Persamaan HKSA seri senyawa turunan Pirazolin tersubtitusi $1-\mathrm{N}$ dari Thiosemicarbazone adalah: $\log$ IC50 $=0,869$ $+(0,081 \times$ TPSA $)+(0,018 \times$ HF $)+(0,527 \times$ E-HOMO $)+(3,378 \times$ E-LUMO $)+(-16,938 x$ Glob $)+(0,234 \times \log P)$. Deskriptor yang berpengaruh signifikan terhadap aktivitas Antiamuba senyawa turunan Pirazolin tersubtitusi 1-N dari Thiosemicarbazone adalah Koefisien partisi $(\log \mathrm{P})$, Energi LUMO, Energi HOMO, Kalor pembentukan (HF), Globularitas (Glob) dan total daerah permukaan polar (TPSA). Perancangan senyawa baru turunan Pirazolin dalam penelitian ini menghasilkan 5 senyawa baru yang memiliki aktivitas biologis lebih baik dari senyawa penuntun. Interaksi antara senyawa usulan yang memiliki aktivitas terbaik dengan reseptor O Acetyl-L-Serine Sulfhydrylase (EHOASS) dipelajari melalui molecular docking. Semua senyawa usulan mampu melakukan interaksi spesifik dengan binding site reseptor melalui ikatan hidrofobik. Residu asam amino EHOASS yang sering dijumpai sebagai sisi pengikatan dengan senyawa usulan dalam adalah Thr85, Ser86, Lys58, Thr89, Ile140, Gln159, Phe160, Gly192, Met136, Gly236, Ile237, Phe241, Ala239..

\section{DAFTAR PUSTAKA}

Abid, M., Azam, A., 2005, Synthesis and antiamoebic activities of $1-\mathrm{N}$-substituted cyclised pyrazoline analogues of thiosemicarbazones, Bioorg. Med. Chem., 13 (6), 2213-2220.

Bhoyar, A. D., Vankhade, G. N., Rajput, P. R., 2011, Synthesis and Study of Cholosubstituted 4-aroyl Pyrazolines and Isoxazolines and THEIR effects on Inorganic Ions in Blood serum in Albino
Rats, Nusantara Bioscience Journal, 3 (3), 118-123.

Damme, S.V., 2009, Quantum Chemistry in QSAR, Quantum Chemical Descriptors, Use, Benefits and Drawbacks, Thesis, Departments of Inorganic and Physical Chemistry Faculty of Sciences Universiteit Gent, Netherland.

Iyyappan, C., Praveen, C., Hemalatha, K., Girija, K., 2010, Design, Preliminary Qsar Study and Drug-Likeness Score of Isobenzofuran Analogues. Int. J. Pharma. Bio. Sci.,1 (4).

La Kilo, J., 2014, Kajian Hubungan Kuantitatif Struktur-Aktivitas Antimalaria Turunan Quinolon-4(1h)-Imine Menggunakan Deskriptor Hasil Perhitungan Metode Ab Initio HartreeFock, Tesis, Program Pascasarjana Universitas Gajah Mada, Yogyakarta.

Lipinski, C.A., Lombardo, F., Dominy, B.W., Feeney, P.J., 2001, Experimental and Computational Approaches to Estimate Solubility and Permeability in Drug Discovery and Development Settings, Adv. Drug Deliv. Rev., 46 (13),3-26.

Mangeron, 2006, New-I-amdosulphonylphenoxyacctyl-3-methyipyrazolin-5-one Derivatives, Rom. Biotech. Lett., 3 (11), 2767-2772.

Nagpal, I., Raj, I., Subbarao, N., \& Gourinath, S., 2012, Virtual Screening, Identification and In Vitro Testing of Novel Inhibitors of O-acetyl-L-serine Sulfhydrylase of Entamoeba Histolytica, PLoS One, 7 (2), e30305.

Nogrady, T., 1992, Kimia Medisinal, Pendekatan Secara Biokimia, Penerbit ITB, Bandung.

Pranowo, H.D., 2009, Peran Kimia Komputasi dalam Desain Molekul Obat Pidato Pengukuhan Jabatan Guru Besar Pada Fakultas Matematika dan Ilmu Pengetahuan Alam Universitas Gadjah Mada, Universitas Gajah Mada, Yogyakarta.

Putri, E.S.Y., Tahir, I., 2004, Kajian Hubungan Kuantitatif antara Struktur Elektronik dan Aktivitas Senyawa Indolilalkilamina berdasarkan Hasil Perhitungan Metode AM1, Jurnal Eksakta 6 (1), 10-18. 
Rembet, J.G., 2011, In-Silico Screening Senyawa Turunan Quinazoline sebagai Inhibitor Epidermal Growth Factor Receptor Tyrosine Kinase (EGFR-TK), Skripsi, Universitas Negeri Gorontalo, Gorontalo.

Sharma, S., Kaur, S., Bansal, T., Gaba, J., 2014, Review on Synthesis of Bioactive Pyrazoline Derivatives, Chem Sci Trans, 3 (3), 861-75.

Siswandono, Soekardjo, B., 2008, Kimia Medisinal, Airlangga University Press (AUP), Surabaya.

Syahputra, G., Ambarsari, L., Sumaryada, T., 2011, Simulasi Dockin Kurkumin Enol, Bisdemetoksikurkumin dan Analognya sebagai Inhibitor Enzim12Lipoksigenase, Jurnal Biofisika, 10(1), 55-67.
Tahir, I., Wijaya, K., Putri, E.S.Y., 2004, Aplikasi Pemisahan Data secara Acak pada Analisis Hubungan Kuantitatif Struktur Elektronik dan Aktivitas Senyawa Indolialkilamina, Seminar Nasional Hasil Penelitian Farmasi, 190-200.

Verma, R.P., Hansch, C., 2011, Use of 13C NMR Chemical Shift as QSAR/QSPR Descriptor, Chem. Rev., 111(4), 28652899.

Widyastuti, I.K., 2011, Prevalensi Infeksi Amebiasis Pada Siswa Madrasah Ibtidaiyah Islamiyah Desa Simbang Wetan Kecamatan Buaran Pekalongan, Jawa Tengah, Artikel Penelitian, Fakultas Kedokteran Universitas Diponegoro, Semarang. 